\title{
JOURNAL OF RESEARCH
}


ISSN awaiting receipt (print)

ISSN awaiting receipt (online)

\section{AMERICAN JOURNAL OF RESEARCH}

№ 2 (2), February 2017

Social Science and Humanities

USA, Michigan 


\section{American journal of research}

\section{Founder and publisher Robert Hart}

Published since January 2017 year. Issued Monthly.

Editorial office: Mailing address: 8223 Lakeshore Rd., Lexington,

Michigan 48450, USA Phone: +1 348-498-3736

Internet address: http:/ / www.journalofresearch.us

E-mail: info@journalofresearch.us

Circulation 200 copies. Free of charge.

\begin{tabular}{|c|c|c|}
\hline Chief in Editor & Robert Hart & $\begin{array}{l}\text { Country: USA, Michigan } \\
\text { Area: (social science and humanities) } \\
\text { E-mail: info@journalofresearch.us }\end{array}$ \\
\hline \multicolumn{3}{|l|}{ Editorial board } \\
\hline $\begin{array}{l}\text { Professor in National University of } \\
\text { Cordoba in Argentina }\end{array}$ & $\begin{array}{l}\text { Sebastian } \\
\text { Viqueira }\end{array}$ & $\begin{array}{l}\text { Specialization: Social science and } \\
\text { Humanities } \\
\text { Country: Argentina } \\
\text { sebastianviqueira@gmail.com }\end{array}$ \\
\hline $\begin{array}{l}\text { Assistant professor in Faculty of } \\
\text { security-Scopje }\end{array}$ & $\begin{array}{c}\text { Marjan } \\
\text { Gjurovski }\end{array}$ & $\begin{array}{l}\text { Specialization: Social science and } \\
\text { Humanities } \\
\text { Country: Macedonia } \\
\text { Mar.Gjurovski@gmail.com }\end{array}$ \\
\hline Doctor of science, professor & $\begin{array}{l}\text { J. Edward } \\
\text { Halcomb }\end{array}$ & $\begin{array}{l}\text { Specialization: Social science and } \\
\text { Humanities } \\
\text { Country: USA } \\
\text { Epoch13@att.net }\end{array}$ \\
\hline $\begin{array}{l}\text { Professor in Eötvös Loránd } \\
\text { University }\end{array}$ & Judit Kozma & $\begin{array}{l}\text { Specialization: Social science and } \\
\text { Humanities } \\
\text { Country: Budapest, Hungary }\end{array}$ \\
\hline $\begin{array}{l}\text { Professor in Criminology at the } \\
\text { Faculty of Criminal Justice and } \\
\text { Security University of Maribor }\end{array}$ & Gozard Mesko & $\begin{array}{l}\text { Specialization: Social science and } \\
\text { Humanities } \\
\text { Country: Slovenia }\end{array}$ \\
\hline Assistant professor & Dave Haddad & $\begin{array}{l}\text { Specialization: Social science, arts } \\
\text { Country: USA } \\
\text { haddaddrum@yahoo.com }\end{array}$ \\
\hline Professor in University of Utrecht & Dina Siegel & $\begin{array}{l}\text { Specialization: Social science } \\
\text { Country: Netherlands } \\
\text { Dina.S@uu.nl }\end{array}$ \\
\hline $\begin{array}{l}\text { Assistant professor in Faculty of } \\
\text { Law, University of Zagreb }\end{array}$ & $\begin{array}{l}\text { Aleksandar } \\
\text { Marsavelski }\end{array}$ & $\begin{array}{l}\text { Specialization: Social science and } \\
\text { Humanities } \\
\text { Country: Croatia }\end{array}$ \\
\hline Doctor of science & $\begin{array}{c}\text { Mihails } \\
\text { Černousovs }\end{array}$ & $\begin{array}{l}\text { Specialization: Social science and } \\
\text { Humanities } \\
\text { Country: Latvia }\end{array}$ \\
\hline
\end{tabular}

๑ Collective of authors

${ }^{\circ}$ American journal of research 
Contents

\begin{tabular}{|c|c|c|}
\hline & & pp. \\
\hline 1. & $\begin{array}{c}\text { Miruktamova Feruza Lutfullayevna } \\
\text { LEGISLATIVE REGULATION OF THE RIGHT OF THE } \\
\text { CHILD IN UZBEKISTAN }\end{array}$ & 5 \\
\hline 2. & $\begin{array}{c}\text { Mirkhamidova Sevara Mirmakhmudovna } \\
\text { RESEARCH OF LEVEL OF STIGMATIZATION AND } \\
\text { DISCRIMINATION IN THE CITY OF TASHKENT }\end{array}$ & 13 \\
\hline 3. & $\begin{array}{c}\text { Kurbonova Gulsara Sodikovna } \\
\text { ANALYSES OF OEKOUMISTICAL OF PRASEOLOGICAL } \\
\text { UNITS IN FRENCH AND UZBEK }\end{array}$ & 22 \\
\hline 4. & $\begin{array}{c}\text { Yakhyoyeva Zebiniso Musaevna } \\
\text { ANALYSE INTERACTION BETWEEN SEMANTIC- } \\
\text { SYNTACTICAL AND LEXICO-GRAMMATICAL } \\
\text { CATEGORIES }\end{array}$ & 30 \\
\hline 5. & $\begin{array}{c}\text { Xodjaqulova Nargiza Xosiyatkulovna } \\
\text { CONCEPTUAL PROBLEMS OF CULTUROLOGY IN THE } \\
\text { CONTEMPORARY LANGUAGE SYSTEM }\end{array}$ & 39 \\
\hline 6. & $\begin{array}{c}\text { Muborak Norkhodjaeva } \\
\text { MODERN PEDAGOGICAL TECHNOLOGIES IN TEACHING } \\
\text { FOREIGN LANGUAGES }\end{array}$ & 48 \\
\hline 7. & $\begin{array}{c}\text { Mukhitdinova Firyuza Abdurashidovna } \\
\text { NEW STAGE OF REFORMING PREPARATION OF LEGAL } \\
\text { STAFF IN THE REPUBLIC OF UZBEKISTAN }\end{array}$ & 54 \\
\hline 8. & $\begin{array}{c}\text { Muhayyo Rakhimova } \\
\text { TO THE QUESTIONS OF SUPERVISION OF THE } \\
\text { INDEPENDENTS WORKS OF STUDENTS WHILE } \\
\text { LEARNING FOREIGN LANGUAGES }\end{array}$ & 71 \\
\hline
\end{tabular}




\title{
Miruktamova Feruza Lutfullayevna
}

Independent researcher of the Department of "UNESCO Chair on International Law and Human Rights" of the University of World Economy and Diplomacy in Tashkent

\section{LEGISLATIVE REGULATION OF THE RIGHT OF THE CHILD IN UZBEKISTAN}

\begin{abstract}
: the article examines the role and the significance of the legislative norms of the Republic of Uzbekistan in the field of protection of children's rights. Also, the implementation of the basic principles and provisions of the UN Convention on the Rights of the Child in the national legislation of the Republic of Uzbekistan.
\end{abstract}

Keywords: children's rights, the Convention on the Rights of the Child, children's rights in Uzbekistan, protection of children's rights.

Children's rights are the human rights of children with particular attention to the rights of special protection and care afforded to minors. The Convention on the Rights of the Child (CRC) of 1989 defines a child as any human person who has not reached the age of eighteen years ${ }^{1}$.

1 Convention on the Rights of the Child, G.A. res. 44/25, annex, 44 U.N. GAOR Supp. (No. 49) at 167, U.N. Doc. A/44/ 49 (1989), entered into force Sept. 21990.

Social Science and Humanities 
The United Nations' 1989 Convention on the Rights of the Child, or $\mathrm{CRC}$, is the first legally binding international instrument to incorporate the full range of human rights - civil, cultural, economic, political and social rights. Its implementation is monitored by the Committee on the Rights of the Child. National governments that ratify it commit themselves to protecting and ensuring children's rights, and agree to hold themselves accountable for this commitment before the international community. The CRC is the most widely ratified human rights treaty with 195 ratifications. South Sudan and the United States are the only two countries, which have not ratified the CRC. The CRC is based on four core principles, namely the principle of nondiscrimination, the best interests of the child, the right to life, survival and development, and considering the views of the child in decisions which affect them (according to their age and maturity). The CRC, along with international criminal accountability mechanisms such as the International Criminal Court, the Yugoslavia and Rwanda Tribunals, and the Special Court for Sierra Leone, is said to have significantly increased the profile of children's rights worldwide.

The Republic of Uzbekistan, having joined the UN Convention on the Rights of the Child in 1992, established a reliable legislative basis for the protection of the rights and freedoms of the child. 
In ensuring the rights of the child, Uzbekistan is guided by the main international treaties of the United Nations, such as the International Covenant on Civil and Political Rights², the International Covenant on Economic, Social and Cultural Rights ${ }^{3}$, the Convention on the Elimination of All Forms of Discrimination against Women", the Convention on the Elimination of All Forms of Racial Discrimination ${ }^{5}$ and Convention against Torture and Other Cruel, Inhuman or Degrading Treatment or Punishment ${ }^{6}$. Having joined the main six international instruments of the United Nations, the Republic of Uzbekistan has undertaken international obligations to ensure the protection of the rights of the child in accordance with universally recognized principles and norms of international law.

The Constitution, laws, decrees and resolutions of the President, Cabinet of Ministers decrees and other normative legal acts, regulate the rights of the child. In order to implement the provisions of the convention, improve the legal framework in this area, the country has adopted such laws as "On Guarantees of the Rights of the Child", "On Guardianship and

2 Human rights. Collection of international treaties. Volume 1 (part one). Universal contracts. United Nations Geneva. 1994, P. 22.

${ }^{3}$ Human rights. Collection of international treaties. Volume 1 (part one). Universal contracts. United Nations Geneva. 1994. C. 8.

${ }^{4}$ Human rights. Collection of international treaties. Volume 1 (part one). Universal contracts. United Nations Geneva. 1994. P. 167

5 Human rights. Collection of international treaties. Volume 1 (part one). Universal contracts. United Nations Geneva. 1994. P. 73.

${ }^{6}$ Human rights. Collection of international treaties. Volume 1 (part one). Universal contracts. United Nations Geneva. 1994, p. 336. 
Trusteeship", "On Combating Trafficking in Human Beings", "On Social Protection of Persons with Disabilities in the Republic of Uzbekistan" ( New edition), "On the prevention of neglect and delinquency among minors", "On limiting the distribution and consumption of alcohol and tobacco products," and others.

The Law of the Republic of Uzbekistan "On the Guarantees of the Rights of the Child", adopted taking into account the recommendations of the UN Committee on the Rights of the Child, not only consolidates the rights of children, but also develops the provisions of the Convention by regulating the rights of the child to private property, housing and work, Socially vulnerable children on the family environment, integration into society, housing rights, social assistance, education, etc. At the national level, measures are being taken to achieve the principle of "Healthy mother - a healthy child." It is also symbolic that one of the first orders instituted in the republic is the Soglom Avlod Uchun Order.

40 percent of the republic's population are children, and 64 percent are young people under $30^{7}$. In this regard, the priority direction of the state policy in the field of human rights and freedoms is the creation of favorable conditions for their physical, intellectual and spiritual

\footnotetext{
${ }^{7}$ http://www.narodnoeslovo.uz/index.php/homepage/zhamiyat/item/8210-deti-nashe-budushchee Social Science and Humanities

Generalization of Scientific Results 
development, as well as comprehensive support for large families and children deprived of a family environment.

In Uzbekistan, a number of policy documents have been implemented aimed at creating the necessary organizational and legal mechanisms and socio-economic conditions for the realization of the entire range of child rights. They pay great attention to the child's social protection, the realization of his rights in the sphere of education, health protection, and legal protection by competent state bodies, civil society institutions and parents, as well as the persons who replace them. Because of comprehensive measures, maternal and infant mortality has declined over the past five years. The average life expectancy of the population has increased by 7.5 years $^{8}$. On these indicators, our country has fully achieved the relevant Millennium Development Goals of the UN. Of course, this confirms the correctness and effectiveness of the model chosen by our state health.

Over the years, measures have been developed and consistently implemented to create favorable conditions for the birth and upbringing of a healthy generation with the aim of achieving a long-term effect improving the gene pool of the nation, raising the medical culture, duration and quality of life in the family. In the framework of the State

${ }^{8}$ http://www.narodnoeslovo.uz/index.php/homepage/zhamiyat/item/8210-deti-nashe-budushchee Social Science and Humanities 
Program "The Year of a Healthy Mother and Child," huge work continues in this direction. For example, in September this year, the Law "On State Youth Policy" was adopted. It fixes such priority areas of the state youth policy as the provision of social, economic, political and other rights and interests, affordable and high-quality education for young people, promoting the physical, intellectual and moral development of the younger generation, creating conditions for employment and youth employment.

Functionally, the issues of protecting the rights of children and childhood in our country are dealt with in the center and in the localities by the bodies of social protection of the population, education, health care, internal affairs, as well as charitable, youth, children's and other public organizations. In fact, Uzbekistan has formed a system of bodies and organizations that protect the rights of the child in the person of the legislative, executive and judicial authorities, prosecutors, advocates, public structures that promote the rights of the child.

The deepening of international cooperation of Uzbekistan with international organizations plays an important role in the timely and qualitative implementation of international standards and foreign best practices in the sphere of the rights and freedoms of the child. The government's efforts to ensure the rights of the child are carried out through the development and implementation of programs supported by the United Nations Children's Fund (UNICEF) in Uzbekistan. Thus, a joint Social Science and Humanities 
Country Program was signed for 2016-2020 aimed at ensuring access of women and children to quality basic services. Similar programs have become traditional for Uzbekistan's cooperation with UNICEF.

The ongoing work in the country to strengthen the rights and legitimate interests of children and youth, strengthen the responsibility of state and public organizations in the implementation of state youth policy, improve the effectiveness of measures taken in this area, create the necessary conditions contribute to the birth, education of a healthy, harmoniously developed generation that meets the requirements of the XXI Centuries.

\section{References:}

1. Initial reports of States parties due in 2011, Uzbekistan, CRC / C / OPSC / UZB / 1, 25 January 2012

2. Human rights. Collection of international treaties. Volume 1 (part one). Universal contracts. United Nations Geneva.

3. The Constitution of the Republic of Uzbekistan. G. 1992

4. Initial reports of States parties due in 2011, Uzbekistan, CRC / C / OPSC / UZB / 1, 25 January 2012

5. CRC - Uzbekistan - CRC / C / 104 / Add.6 (2005)

6. http://www.narodnoeslovo.uz/index.php/homepage/zhamiy at/item/8210-deti-nashe-budushchee

7. http://nhrc.uz/ru/news/center_news/745/ 


\section{The author information}

In 2010, F.Miruktamovarecieved Master`s degree on "Property rights of minors".

At present is scientific research for the degree of PHD on the theme "International standards of juvenile justice" in the specialty 12.00 .10 "International law" at University of world economy and diplomacy.

F.Miruktamovais the author of 1 monograph "the Property rights of minors" and about 40 scientific articles in international and domestic journals.

Main publications:

1. Institute of children's ombudsman as a mechanism of protection of juveniles' rights. International journal of law (India). September 2016.

2. Ensuring children's rights in Uzbekistan. International journal of law (India). December 2016.

3. Theoretical and international legal aspects of the application of measures to remove juvenile offenders from the justice system. Journal of Democratization and Human Rights. 2016/4 (Uzbekistan).

4.The role of the probation service in protecting the rights of the child. "public opinion and human rights". 2016 /2 (Uzbekistan).

Scientific interests: international legal cooperation in the field of human rights, UN activities in the field of child's rights, the rights of the child.

Address: University of world economy and diplomacy 100192, Uzbekistan, Tashkent city Mustakillik av., 54. email: miruktamova@mail.ru

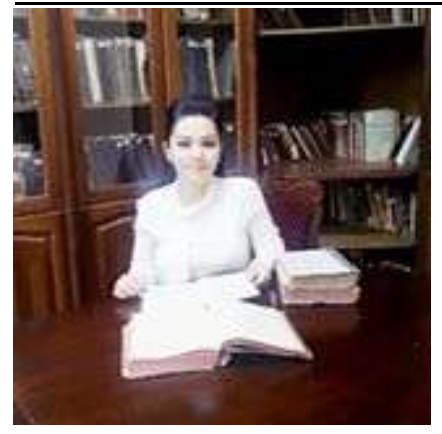

USA, Michigan 
American Journal of Research

№ 2 (2), February 2017 www.journalofresearch.us

info@journalofresearch.us

\section{Mirkhamidova Sevara Mirmakhmudovna}

Department of Public health and health care, Tashkent medical academy

\section{RESEARCH OF LEVEL OF STIGMATIZATION AND DISCRIMINATION IN THE CITY OF TASHKENT}

INTRODUCTION: Since the beginning of the HIV / AIDS epidemic, stigma and discrimination have created a breeding ground for HIV transmission and have greatly increased the negative impact of the epidemic. HIV stigma and discrimination continue to manifest itself in all countries and regions of the world, creating serious obstacles to preventing the spread of infection, providing adequate care, support and treatment, and mitigating the impact of the epidemic. Stigma associated with HIV / AIDS hinders an open discussion of the causes of the epidemic and the implementation of appropriate countermeasures. Open recognition of HIV / AIDS is a prerequisite for successful mobilization of the state, communities and individuals to counteract the epidemic. The silence of this problem can lead to the denial of its existence and hinders the adoption of urgent measures to solve it. Because of this, people living with HIV / AIDS are treated only as a source of problems, although they can take part in curbing the epidemic and establishing control over it. Stigma associated Social Science and Humanities 
American Journal of Research

№ 2 (2), February 2017 www.journalofresearch.us info@journalofresearch.us

with HIV / AIDS is based on numerous factors, including misunderstanding of the disease, misconceptions about the ways of HIV transmission, lack of access to treatment, irresponsible media reports on the epidemic, the incurable nature of AIDS, prejudices and fears for a number of delicate Social issues such as sexual relations, disease and death, illegal drug use. Stigma can lead to discrimination and other human rights violations, which has a very negative impact on the well-being of people living with HIV / AIDS. In all countries of the world, there are many cases when people living with HIV / AIDS were denied access to medical services, were not employed and deprived of their rights to education and freedom of movement. The unanimous recognition of the importance of combating stigma and discrimination in relation to HIV / AIDS is reflected in the "Declaration of Commitment on HIV / AIDS" adopted at the UN General Assembly Special Session on HIV / AIDS in June 2001. The Declaration notes that combating stigma and discrimination is a prerequisite for effective prevention and treatment activities and stresses that discrimination based on HIV-positive status is a violation of human rights. Discrimination against HIV is not only a violation of human rights; With such discrimination and stigma, it is necessary to fight to achieve public health goals and overcome the epidemic. Response to the HIV / AIDS epidemic is a complex of prevention and care activities, and the negative effects of stigma and discrimination can be seen in all these Social Science and Humanities 
aspects of the response. Ideally, people should be able to seek voluntary and confidential counseling and testing to find out their HIV status without fear of consequences. People who have received a negative result should receive a consultation on the prevention of infection in order to maintain this status. Those who received a positive test result should have access to treatment and care and, if necessary, preventive counseling to protect others from infection and themselves from re-infection. People living with HIV / AIDS should be able not to hide their status and receive support in their communities. On their example, people see what the risk leads to, see what they have to worry about, and this helps prevention, care and treatment.

Social stigmatization creates obstacles at all stages of this cycle, as, by definition, such an environment does not promote the support of others. Stigma and discrimination against HIV / AIDS undermine all prevention efforts, because of fear of the reaction of others, people are afraid to find out if they are infected or not and are not looking for information on how to reduce their own risk and change their behavior. Because of this, the ability of individuals and communities to protect themselves from infection decreases. Fear of stigma and discrimination prevents people living with HIV from revealing their status even to family members and sexual partners. Closeness of information about HIV infection and fear of stigma and discrimination make people think that they themselves do not risk Social Science and Humanities 
getting HIV. HIV-related stigma and discrimination also means that people living with HIV / AIDS have far fewer opportunities to receive care and support. Even those who are not actually infected, but are connected with infected people - their spouses, children, people caring for them - suffer from stigma and discrimination, which further exacerbate the personal suffering caused by the disease. The shame of HIV / AIDS - a manifestation of stigma, which some authors call "internal" stigma, can also prevent people living with HIV / AIDS from seeking treatment, care and support services and exercising other rights such as right For work, schooling, etc. This shame has a powerful psychological impact on the selfesteem of people living with HIV / AIDS, their ability to adapt to their status, makes them vulnerable to accusations, depression and self-isolation. This situation is exacerbated even more when people are already isolated and stigmatized because they belong to certain groups of the population, such as injecting drug users, men who have sex with men, sex workers or migrants. With the availability and accessibility of health services, stigma can increase the difficulty of adherence to treatment. This tendency to conceal one's status, difficulties in applying for treatment, care and support services themselves fuel stigma and discrimination, thus further exacerbating the vicious circle. The fact is that such stereotypes and fears remain unchanged if communities recognize people living with HIV / AIDS only when their health is already weakened and they are at the last, Social Science and Humanities 
symptomatic stage of the disease. Silencing the problems of HIV infection increases the stigmatization of already vulnerable people. Non-disclosure of the fact of HIV infection in the family often leads to the fact that people do not make plans for the future. After the death of the main breadwinner, orphans and other family members who survive this loss are deprived of their livelihoods and often fall into social isolation after it becomes known that their families have been affected by AIDS.

Stigma is described as a dynamic process of devaluation of the individual, which "largely discredits" the individual in the eyes of others. Qualities on the basis of which stigma occurs can be the most random - for example, skin color, manner of speaking or sexual orientation. In different cultures or societies certain qualities are considered to be defamatory or unworthy. HIV-related stigma is multifaceted and tends to develop and increase negative factors due to the fact that HIV and AIDS are associated with behaviors that are already considered marginal, such as sex work, illicit drug use, homosexuality or trans sexual relations. In addition, it enhances the fears of "outsiders" and representatives of vulnerable groups, such as prisoners and migrants. It is widely believed that people living with HIV deserve their fate, because they committed some "wrong misconduct". Accusing individuals or certain groups of the population ("not like everyone else"), other members of society do not recognize their own risk, relieve themselves of responsibility for solving the problem and Social Science and Humanities 
providing care to the victims. The image of people living with HIV in the press and on television can intensify the accusatory moods, if such definitions of HIV / AIDS as "women's illness", "addict's illness", "African disease" or "plague of homosexuals" are used. Religious ideas of sin can also help preserve and strengthen the notion that HIV infection is a punishment for misconduct. Stigma also manifests itself in linguistic means. Since the beginning of the epidemic, strong metaphors, due to which HIV is associated with death, guilt and punishment, crimes, horror, have created stigma and legitimized it. The use of such language is associated with yet another aspect underlying the accusations and rejection, and further strengthens this aspect: it is the fear of people facing a deadly disease. To a certain extent, stigma based on fear is caused by people's fear of the consequences of HIV infection, particularly high mortality (especially if treatment is not provided widely), or fear of contracting, or fear of those who saw the state of AIDS patients at the last stage of the disease. Stigma has deep roots and is based on the criteria of everyday life. Although AIDS-related images are different, the fundamental basis of AIDS stigma contributes to social inequality. This is especially true of gender, race and national inequality, as well as sexual orientation. For example, women and men are often treated differently if they are infected with HIV or if they are only suspected of it: most often they are blamed on a woman, even if her husband was the source of the Social Science and Humanities 
infection; In addition, infected women are less likely that they will not be rejected by the communities to which they belong. This process is associated with long-standing gender inequality, reinforced by perceptions of male and female qualities, which have at all times been the reason for women to be accused of transferring any sexually transmitted infections and attributing them a penchant for "adultery". Similarly, allegations against homosexuals and transgender people are based on long-standing stigmatization in connection with public perceptions of their lifestyle and sexual preferences. Racial and ethnic stereotypes also contribute to the stigma associated with AIDS. For example, when describing an epidemic, racist statement about "the sexual promiscuity of Africans" are often used, and in developing countries, on the contrary, they speak of "immorality" of the West. Finally, vulnerability to HIV among communities living in poverty reinforces the already stigmatizing of economically disadvantaged groups of the population. Through these associative representations, stigma is associated with the notions of power and domination in society as a whole, shaping and amplifying inequality, which causes some populations to experience a sense of superiority, while others feel themselves to be inferior. The fact that HIV infection is associated with already stigmatized populations and behaviors reinforces pre-existing inequalities and further promotes the formation and reproduction of unjust power relations. Stigma that existed earlier is complemented by HIVSocial Science and Humanities 
American Journal of Research

№ 2 (2), February 2017 www.journalofresearch.us

info@journalofresearch.us

related stigma, not only because stigmatized groups are even more stigmatized because they are associated with HIV infection, but also because there may be an opinion in society that HIV-infected people belong to marginalized groups.

The stigma and discrimination bound to the HIV status remain the key factors interfering realization of the cascade of services in treatment and assistance at HIV infection. For development and implementation of programs of the rights referred on protection and interests of the people living with HIV it is important to possess information on the developing situation.

RESEARCH OBJECTIVE: Collection of information about problems of the people living with the HIV bound to stigmatization and discrimination in Tashkent.

Tasks:

- to collect data on various events bound to stigmatization and discrimination on a HIV indicator within concrete community;

- to compare influence of a specific problem on life of the people living with HIV in this country and in the different countries;

- to track changes and to answer a question, "The situation with stigmatization and discrimination of the people living with HIV in this community in recent years improves or worsens?" 
MATERIALS AND METHODS: The methodology of the global research "Index of Stigmatization of the People Living with HIV" has been used. The research has been conducted by method of the individual standardized interview. The research was conducted within the project financed by the state support of the non-profit non-governmental organizations realizing socially important projects and participating in development of institutes of civil society. The volume of selection has made 100 respondents. The received selection has allowed defining key tendencies in the studied questions.

RESULTS: A third of respondents (33\%) ever faced this or that type of discrimination or stigmatization from people around for the reasons including the HIV status within the last 12 months. In addition, the majority (90\%) having a life experience with HIV more than 1 year was noticed that a year ago they would note larger quantity of cases of discrimination and stigmatization. It is more than a half of respondents (58\%) who underwent prosecutions/restrictions/discrimination for the last 12 months in connection with their HIV status, specify the following reasons: people around are insufficiently informed on ways of transfer of HIV infection (42\%), are afraid will catch by means of casual contact $(16 \%)$, think and actively show that to have HIV infection shamefully (16\%). $6 \%$ of respondents faced refusal in a work arrangement. The refusal in medical care, including the stomatologic help, was noted by $22 \%$ of respondents. Social Science and Humanities 
Participants of a research noticed that for last 12 months they have feeling of the fault - $60 \%$, feel shame - 40\%, 55\% accuse themselves of the incident, $15 \%$ notice that they felt desire to commit suicide. $17 \%$ of respondents noticed that within last 12 months their rights in connection with their HIV status were violated. More than a half $(78 \%)$ of respondents was noticed that they don't feel an opportunity to exert impact on decisionmaking in formation of policy for the people living with HIV, at any level (regional, federal, national). Consultation to the test for HIV received only $8 \%$ of respondents. Workers of health care most often became perceptible respondents as the most inclined to implication of discrimination against HIV-positive patients, so discrimination and strong discrimination were noted in total by $30 \%$ of respondents.

CONCLUSIONS: The conducted research allowed key references on improvement of the help to the people living with HIV in Tashkent. In many respects results correlated with a stigma index research. 
American Journal of Research

№ 2 (2), February 2017 www.journalofresearch.us

info@journalofresearch.us

\section{The author information}

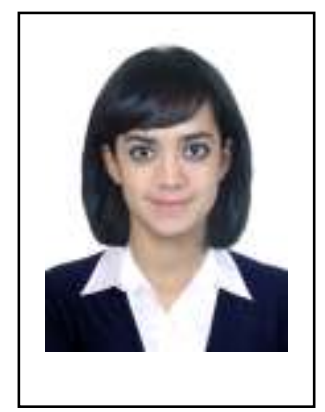

Mirkhamidova Sevara Mirmakhmudovna

Since 2016: The assistant to department of public health, the organization and managements of health care in TMA

Nationality: Uzbek

Education: the highest

I have ended:

- 2009. Tashkent pediatric medical institute bachelor

- 2011. Tashkent pediatric medical institute magistracy

Specialty by training: Managements and organization of health care and nurse business 
American Journal of Research

№ 2 (2), February 2017 www.journalofresearch.us

info@journalofresearch.us

\section{Kurbonova Gulsara Sodikovna}

Professor, Chaire of French philology, National University of Uzbekistan

\section{ANALYSES OF EKOUMISTICAL OF PRASEOLOGICAL UNITS IN FRENCH AND UZBEK}

In this article, proper names in the phraseological units are researched. The development of existence of toponymic component in phraseological units in French and Uzbek languages are also analyzed in it.

Key words: œkoumène, toponymy, phraseological units, proper name, national character.

\section{АНАЛИЗ ОЙКОНОМИЧЕСКИХ ФРАЗЕОЛОГИЗМОВ ВО ФРАНЦУЗСКОМ И УЗБЕКСКОМ ЯЗЫКАХ}

\section{АННОТАЦИЯ}

В данной статье рассматриваются историко-культурные самобытности народа на примере французских и узбекских ойкономических фразеологизмов.

Ключевые слова: ойконим, топоним, фразеологические единицы, имя собственное, национальный характер, историко-культурный аспект, коннотативное значение 
American Journal of Research

№ 2 (2), February 2017 www.journalofresearch.us info@journalofresearch.us

Ойконимы как именования населенных пунктов представляют собой один из самых важных и употребительных разрядов именований топонимического пространства. Населенные пункты как рукотворные объекты четко выделяются из окружающего ландшафта9. Вследствие наибольшей (по сравнению с другими названиями) экстралингвистической обусловленности ойконимы легко входят вразличного рода устойчивые сочетания слов. Своеобразие ойконимов позволяет, при всем различии лексикограмматического состава, значения и прочего, выделить их в особую группу.

Названия городов, сел, деревень и всех других видов поселений в обжитой местности выполняют основную адресную роль поэтому абсолютно преобладают среди всех других топонимов. Поэтому ойконимические фразеологизмы преобладают среди других видов топонимических фразеологизмов во французском языке.

Существует определенная соотнесенность между наличием или отсутствием у ойконима коннотативного значения и степенью мотивированности оборота в целом. Большинство фразеологических единиц с ойконимами характеризуется отсутствием или малой степенью мотивированности, то есть Значительной слитностью

9 Хисаметдинова Р.Ф. Топонимы и их дериваты в языковой системы: На материале немецкого и русского языков. Автореферат. Уфа: 2000.

Social Science and Humanities 
American Journal of Research

№ 2 (2), February 2017 www.journalofresearch.us info@journalofresearch.us

частей. Значение ФЕ может и не выводиться из значения составляющих ее компонентов. Во французском языке примерами немотивированных или слабо мотивированных ФЕ могут быть следующие выражения: œuf de Numberg «старинные часы, луковица»чу̀нтак соатнинг қадимий тури (букв.: “яйцо из Нюнберга"); boîte de Numberg «музыкальная шкатулка с танцующими куколками» - қу тисимон мусиқа асбоби (букв.: “шкатулка из Нюрнберга"); saucissondeBologne (разг.) «толстый, коротконогий человек, коротышка»-пакана паст бупили (букв.: “сосика из Болоньи”); avoirdesnerfs à Berlin «быть в состоянии крайнего нервного возбуждения; быть раздраженным» - дарғазаб булмоқ (букв.: “иметь нервы в Берлине").

Значение многих французских ойконимических фразеологизмов также может быть выявлено в результате восприятия этимологии, которой нагружен ойконим, например: représenter les armes de Bourges «быть ослом, дураком»-ахмоқ қилмоқ, лақиллатмоқ (букв.: “показать герб Буржа"). /Бурж - город в Центральной Франции при слиянии рек Эрен и Орон. На гербе города Бурж был изображен осел, сидящий на диване. Согласно утверждению ряда исследователей, осел олицетворял римского управляющего, назначенного императором Цезарем. В словаре Гийтара (1842) указанно, что это является намеком на важного на вид, но глупого Social Science and Humanities 
American Journal of Research

№ 2 (2), February 2017 www.journalofresearch.us info@journalofresearch.us

преподавателя университета этого города/; berger de Mantoue / cygne de Mantoue «пастух / лебедь из Мантуи (о Виргилии)». /Близ города Мантуи на севере Италии есть местечко Пистоле (древнее название Андес, Andes), которое считается родиной Вергилия/; ilvientde Marseille «преувеличивать, привирать, сочинять небылицы» (букв.: “он приезжает из Марселя"). //Люди, живущие н юге Франции славятся преувеличением и рассказами всяких неправдоподобных вещей/.

Рассмотрение фразеологических единищ с ойконимами убеждает нас в том, что для них характерно определенное метасемиотическое свойство, а именно отсутствие стилистической нейтральности.

Их предпочтительное употребление в ряде случаев, вместо соответствующих синонимических свободных словосочетаний, свидетельствует о том, что они имеют несомненную экспрессивную окрашенность, то есть не только обозначают явление как таковое, но до какой-то степени выражают отношение к нему говорящего. Некоторым из них свойственна эмоциональная «приподнятость» (франц. Homme de Sedan «герой Седана», о Наполеоне III; ventre de Paris «чрево Парижа», место кипения сил и страстей буржуазного общества),для большинства, однако, характерна «сниженная» 
American Journal of Research

№ 2 (2), February 2017 www.journalofresearch.us info@journalofresearch.us

стилистическая окрашенность ${ }^{10}$. Последние употребляются преимущественно в устной речи (часто в профессиональной или узко локальной сфере) с оттенками фамильярности, насмешки и т.д. франц. Il est venu à Paris en sabots «он был бедным, когда пришел в Париж, где и разбогател» (букв.: “он пришел в Париж в сабо”); envoyerqnàPontoise «отправить кого-либо к черту на куличках» дунёнинг нариги бурчагина жӯнатмок; Ila été à Saint-Malo (les chiens lui ont mange les mollets / les os) (щутл.) 1) «он очень худ»; 2) «у него очень тонкие ноги» (букв.: “он был в Сен-Мало, собаки отгрызли ему икры / ноги"). Вместе с тем, образность передачи явления присутствует постоянно.

Как известно ойконимы подразделяются на астионимы (названия городов) и хорионимы (названия сельских поселений). Частность употребления того или иного астионима зависит от той роли, которую играл город в жизни государства на протяжении всей его истории. Хорионимы встречаются реже, эта группа составляет в узбекском языке около 6 \%, 6 ФЕ, во французском - 8.5 \%, ФЕ. Это объясняется тем, что астионимы имеют намного больше ассоциаций, чем хорионимы.

10 Беленькая В.Д. Некоторые лингвистические категории топонимики // Оронимка. - М.: Наука, 1969, C. 12-15.

Social Science and Humanities 
Во французских локальных астионимических фразеологизмах присутствуют следующие названия городов: Angoulème, Antibes , Beaune, Bercy, Bourges , Cambai , Corbeil, Grenoble, Lagny, Landerneau, Lyon, Marseille, Meaux, Melun, Nanterre, Niort, Orléans, Paris, Pontoise, Rueil, Rouen, Sedan, Saint-Malo, Saint-Michel, Toulouse, Versailles, Vatan.

В узбекских локальных астионимических фразеологизмов встречаются следующие городов и посёлок: Mirzachtœul, Toytépa, Kuva, Tachkent, Samarkand. Например: Ахмоққа Туйтепа нима йулл?”, “Ахмоққа Қува - бир тош”11.[3: 25]

С точки зрения лингвокультурологии представляют большой интерес фразеологические автостереотипы (мнения, суждения, оценки, относимые к своей этнической общности ее представителями) с названиями столиц рассматриваемых государств - Paris.

Хоронима, деревня должна чем-то прославиться, например: франц. c'estlegrefferdeVaugiardquinepeut écrirequandonleregarde «o том, кто не может работать в присутствии других» (букв.: “секретарь Вожира не может писать, когда на него смотрят"). /Согласно старому анекдоту, сектарь деревни Вожирар исполнял свои обязанности при плохом освещении, затыкая даже маленькое окно/; ahuri (abruti) deChailot (уст.) «неотесанный болван» (букв.: “изумленный из Шайо”).

11 Шомақсудов Ш., Шорахмедов Ш. Маънолар махзани. “Ӯзбекистон миллий энциклопедияси”. Давлат илмий нашриёти. Тошкент, 2001.

Social Science and Humanities 
American Journal of Research

№ 2 (2), February 2017 www.journalofresearch.us info@journalofresearch.us

/Шайо - название бывшей деревни, находившейся на правом берегу реки Сены. Она находилась в непосредственной близости от Парижа и долгое время оставалась вне его черты. С 1784 г. При Людовике XVI Шайо входил в черту столицы. По рассказам, в один прекрасный день жители Шайо были «ошеломлены», узнав о том, что они уже парижане. Ряд исследователей опровергает эту версию, ссылаясь на старинную поговорку, свидетельствующую о более раннем происхождении данного фразеологизма, который, как полагают, отражает отношение горожан к жителям провинции как к людям отсталым.

Форма folledeChaillot, образованная от названия одноименной пьесы Жана Жироду, написанной в 1945 году, заново дала жизнь этому фразеологизму (ср. выражения venirdeChailot; envoyer à Chailot)/. Париж же широко представлен во фразеологических единицах: Paris est le paradis des femmes et l'enfer des chevaux (посл., уст.) «Париж - рай для женщин и ад - для лошадей»; Paris ne s'est pas fait en un jour (посл.) «не сразу дело делается» Jeaun de Paris «переодетый принц, сорящий деньгами»; monsieurdeParis (уст.) «палач»; Paris vaut bien une messe! «Париж стоит мессы!»/О людях, которые ради личной выгоды готовы поступиться с совестью. Большинство историков приписывают это выражение Генриху IV Наваррскому (1553-1610), который в возможность вступить на трон. Social Science and Humanities 
American Journal of Research

№ 2 (2), February 2017 www.journalofresearch.us info@journalofresearch.us

Некоторые исследователи считают, что оно принадлежит министру и другу Генриха IV, герцогу Сюлли/; Parisappartient à ceuxquiseléventtôt «кто рано встает, тому бог подает»; avecun « si » onmettraitParisdansunebouteille (посл.) «если бы да кабы, так во рту росли бы грибы»; avoir un œil à Paris, l'autre à Pontoise «быть косоглазым; один глаз на нас другой на Арзамас» il est venu à Paris en sabots (разг.) «он был бедным, когда пришел в Париж, где и разбогател»; ventre de Paris «чрево Парижа» место кипения сил и страстей буржуазного общества; prendre Paris pour Corbeil (уст.) «совершить большой промах, оплошность»; Il y a des lieux où il faut appeler Paris, et d'autres où il la faut appeler capitql du royaume. «Есть места, где нужно называть Париж Парижем, а есть другие места, где нужно называть его столицей королевства».

Судя по значению и количеству фразеологизмов с названиями столиц, Париж для французов значит больше и имеет больше ассоциаций, чем Лондон для англичан и Нью-Йорк для американцев. Французы превозносят свою столицу во фразеологизмах, ассоциируя ее с центром культурной и общественной жизни, большим, древним, живым, активным городом, предоставляющим много возможностей для самореализации, местом кипения страстей, местом паломничества и поклонения. 
American Journal of Research

№ 2 (2), February 2017 www.journalofresearch.us

info@journalofresearch.us

\section{Литературы:}

1. Беленькая В.Д. Некоторые

лингвистические категории топонимики / / Оронимка.-М.: Наука, 1969, с. 12-15.

2. Хисаметдинова Р.Ф. Топонимы и их дериваты в языковой системы: На материале немецкого и русского языков. Автореферат. Уфа: 2000. С. 182.

3. Шомақсудов Ш., Шорахмедов Ш. Маънолар махзани. “Узббекистон миллий энциклопедияси”. Давлат илмий нашриёти. Тошкент, 2001.

\section{The author information}

Курбонова Гулсара Содиковна старший преподаватель Национального Университета имени Мирзо-Улугбека.

C 2000 года работает в фракультете зарубежной фрилологии b кафедре франиузской филологии.

По специиалности филолог, преподаватель французского языка и

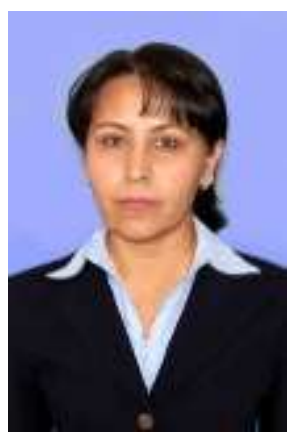
митературы.

Kurbonova Gulsara Sodikovna Professor, Chaire of French philology, National University of Uzbekistan.

Works at University since 2000

Speciality: French and literature

Finished Tashkent State University in 1996

Social Science and Humanities 
American Journal of Research

№ 2 (2), February 2017 www.journalofresearch.us

info@journalofresearch.us

The phraseological unit in the French with a toponymic component

\section{YAKHYOYEVA ZEBINISO MUSAEVNA}

Assistant professor National University of the Uzbekistan

\section{ANALYSE INTERACTION BETWEEN SEMANTIC-SYNTACTICAL AND LEXICO-GRAMMATICAL CATEGORIES}

In this article are analyzed interaction between semantic-syntactical and lexical-grammatical categories.

Key words: attribute, sign, explicant, explicantum, nature of semantic-syntactic.

\section{АНАЛИЗ ВЗАИМООТНОШЕНИЯ МЕЖДУ СЕМАНТИКО - СИНТАКСИЧЕСКИМИ И ЛЕКСИКО - ГРАММАТИЧЕСКИМИ КАТЕГОРИЯМИ.}


American Journal of Research

№ 2 (2), February 2017 www.journalofresearch.us info@journalofresearch.us

В данной статье анализируется анализ взаимоотношения между семантико-синтаксическими и лексико- грамматическими категориями.

Ключевые слова: атрибут, признак, экспликант, экспликандум, семантико-синтаксическая природа.

Отношения между семантико-синтаксическими и лексикограмматическими категориями усложняются в следствие того, что в экспликандуме может выступать не только предметное, но и призрачное значение. Так как призначное значение может выступать двоякой функции, то она тем самым расщепляется на не субстанциональное и субстанциальное призначное значения. С другой стороны, на базе предметных значений могут сформироваться новые призначные значения выражающие какое-либо отношение к данному предмету, например отношение принадлежности. Распределение таких значений, по словам может, оказаться весьма сложным. Как бы, однако ни сложилось их распределения по отдельным словам, различие субстанциональных и несубстанциональных значений остается по своей природе семантико-синтаксическим. Разница между семантико синтаксическими категориями экспликандума и экспликанда и лексико-грамматическими категориями субстанциональных и Social Science and Humanities 
American Journal of Research

№ 2 (2), February 2017 www.journalofresearch.us info@journalofresearch.us

несубстанциональных значений заключается лишь в том, что вторые из них содержат с себе в виде потенциальной категории то, что первые реализуется синтаксическом сочитании.

Переходя от простейших подчинительных сочетаний к более сложным, можно заметить, что в составе законченных предложений основные синтаксические функции усложняются и вместе с ними усложняются грамматическая классификация слов и лексические Значения ${ }^{12}$.

Ближайшим основанием для выделения дополнительных семантико - синтаксических функций является различное отношение экпликанта к составным элементам предложения. До сих пор мы рассматривали между экспликандом и экспликантом так, как если бы речь состояла исключительно из парных «сцеплений», в которых экспликанд выевляет в референте признак, актуальный в этот момент. Мы прибегли к несколько искусственному допущению с целью раскрыть свойства, общие всякому экспликанту. Теперь же, обращаясь к реальному многочленному высказыванию, мы замечаем признака референта принимает разные формы в зависимости от того, каково ее конкретное проявление в предложений.

\footnotetext{
12 Верещагин Е.М., Костомаров В.И. Язык и культура. М., 1983. М. Виноградов В.В. Об основных типах лексических значений слов / / В.В.

Social Science and Humanities 
American Journal of Research

№ 2 (2), February 2017 www.journalofresearch.us

info@journalofresearch.us

Иную функцию выполняет экспликант, указывающий на непосредственное отношение экспликандума к событию, обозначенному предикатом. В сочетаниях типа Он идет; Ребенок разбил чашку; Игра была увлекательной и т .п. Экспликанты актуальны не в плане словесного воссоздания события, в котором замещены определенные референты с другим элементами и их классов, остающимся вне данного предложения, то экспликанты второго рода соотносят референт с событием, а если референтов в предложений много, то всех их вместе с событием выраженном в предложени. Экспликанты первого рода действуют по парадигматической оси; отбирая нужные элементы из класса одноименных объектов, они тем самым оставляют в стороне все остальные элементы данного класса. Экспликанты второго рода действуют по синтагматической оси; они объединяют разные субстанциональные значения (если в предложении их несколько) - независимо их экстенсионалов в единое высказывание. Поскольку, наконец экспликанты первого рода актуальны лишь быть заменены другими экспликантами либо вовсе опущены, не нарушая целостности предложения. Без экспликантов второго рода предложение, как таковое, немеслимо.

Social Science and Humanities 
American Journal of Research

№ 2 (2), February 2017 www.journalofresearch.us info@journalofresearch.us

Экспликанты обоих типов хорошо известны в традиционной грамматике, первые- под именем атрибутов (определений), вторые под именем предикатов (сказуемых). ${ }^{13}$

Расщепление экспликантов на атрибуты и предикаты не остается без последствий и для их экспликандумов. Среди последних приходится теперь различать детерминандумы (определяемые) и предикандумы («дополнения» в широком смысле). Предикандумы это, таким образом, субстанциональные значения, эксплицируемые с помощью предикатов.

Сочетание

субстанционального значения

C несубстанциональным, выступающим в роли атрибута, приводит к образованию атрибутивной группы, тогда как сочитание субстанционального значения с несубстанциональным, выступающим в функции предиката, приводит оброзаванию предложения. Так как предложении все подчинино организующей силе предиката, то атрибутивная группа входит в предложение на правах единого члена предложения, распадаясь внутри себя на детерминандум и атрибуты к нему, атрибутная группа по отношению к предикату остается целестной единицей, едином экспликандумом. Атрибутная группа образует составной член предложения, характер которого

${ }^{13}$ Гак В.Г. Прагматика, узус и грамматика речи / / ИЯШ. 1982.

Social Science and Humanities 
определяется ведущем членной этой группы, субстанциональным значением. Приравнение всей атрибутивной группы к одному из предикандумов является выражением главенствующей роли предиката в предложение.

Второстепенная роль атрибута сравнительно предикатом сказывается и в другом отношении. Если без предиката предложение немыслимо, то атрибут не является его обязательным членом. Как отмечалась выше. Атрибут преследует цели лексической актуализации субстанционольного значения, его экстенсионального уточнения. Если субстанциональные значение достаточно четко выделяется речевой ситуацией или контекстом, то в атрибуте оно не нуждается. Определенные разряды субстанциональных значений появляется обычно в предложении без атрибутов. К ним относятся прежде всего дейктические значения. Местоимения я, mы, он, и т.д. не принимают атрибутов в силу их ситуативной определенности. Не принимают обычна атрибутов и некоторые другие разряды субстанциональных значений, о которых будет сказаны позднее.

Рассматривая отношение определения к определяемому, мы квалифицировали лексическое значение, выступающее в функции определяемого, как субстанциональное. Может показаться примеры типа необычайно радостный, очень рано, упорно работать и т.д. противоречат нашему утверждению. Перед нами Social Science and Humanities 
American Journal of Research

№ 2 (2), February 2017 www.journalofresearch.us info@journalofresearch.us

здесь сочетание призначных слов разных «уровней» или «рангов» подчинения. В предложении он встал очень рано слово очень определяет рано, а рано определяет предикат bcmaл. Двум определениям разных уровней в этом предложении соответствует два разных по уровню определяемых: рано u встал. Каковы же значения этих слов в качестве определяемых, субстанциональны они или нет? Мы сталкиваемся здесь случаями, когда одно и тоже слово совмещает в себе функции экспликанта и экспликандума: будучи экспликандумом по отношению к предшествующему очень, наречие рано в свою очередь является экспликантом по отношению к встал. Такое совмещение функций имеет место сочетании различающихся по уровню экспликантов. ${ }^{14}$

Обособление наречий в особую часть речи связано, очевидно, с необходимостью разграничить различные уровни экспликации. Если, однако в языке различаются лишь два уровня экспликации (наречная форма экспликанта, указывающая на «признак признака», и ненаречная форма, указываюшая на непосредственную связь экспликанта с экспликандумом ), то условие сведения многоступенчатых связей признаков с предметами в реальной

14 Гак В.Г. Семантическая структура слова как компонент семантической структуры высказывания // Семантическая структура слова. М., 1971.

Social Science and Humanities 
American Journal of Research

№ 2 (2), February 2017 www.journalofresearch.us info@journalofresearch.us

действительности к двум уровням в языке является, можно думать, то обстоятельство, что форма « признак признака» является сигналом того, что форма, которой она подчинена, функционально двузначна, что она совмещает в себе функции экспликанта и экспликандума.

Подобное стало актуальном когда в науке о языке лингвокултурологии с ее понятием аппаратом. По своему лексикосемантическому содержанию одни не субстанциональные значения предрасположены функционировать «в первую очередь» как атрибуты и только «во вторую очередь» - как предикаты, тогда как другие не субстанциональные значения предназначают этим функциям другую «очередность». Какие же семантические моменты влияют на размещение не субстанциональных значений по указанным выше подтипам.

\section{СПИСОК ЛИТЕРАТУРЫ}

1.Верещагин Е.М., Костомаров В.И. Язык и культура. М., 1983. М. Виноградов В.В. Об основных типах лексических значений слов // B.B.

2. Гак В.Г. Прагматика, узус и грамматика речи // ИЯШ. 1982.

3. Гак В.Г. Семантическая структура слова как компонент семантической структуры высказывания // Семантическая структура слова. М., 1971.

Social Science and Humanities 
American Journal of Research

№ 2 (2), February 2017

4. Гийом Г. Принципы теоретической лингвистики. М.: Прогресс, 1992.

Social Science and Humanities

USA, Michigan 
American Journal of Research

№ 2 (2), February 2017 www.journalofresearch.us

info@journalofresearch.us

The author information

Яхьяева Зебинисо Мусаевна

Национальный Университет Узбекистана имени Мирзо Улугбек

Закончила Узбекский Государственный Университет Мировых

Языков 2008 год. Специальность: Лингвистика (Французский язык)

Yakhyoyeva Zebiniso Musaevna Assistant professor National University of the Uzbekistan

Finished The Uzbek State World Languages University in 2008 Speciality: Linguistics (French)

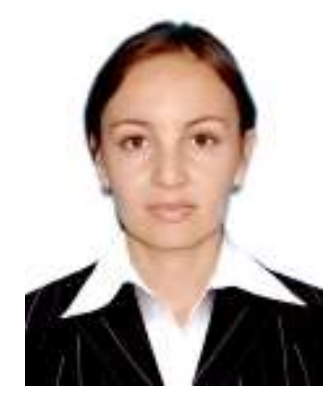

Social Science and Humanities 


\title{
XODJAQULOVA NARGIZA XOSIYATKULOVNA
}

\author{
A senior teacher of English language \\ Tashkent University of Information Technologies, Tashkent, Uzbekistan \\ CONCEPTUAL PROBLEMS OF CULTUROLOGY IN THE \\ CONTEMPORARY LANGUAGE SYSTEM
}

Cultural studies for a long time was considered in our country as "Western science" and appeared in different guises and names. Today, this is an actual and highly sought after humanitarian discipline with a set of specific properties.

Key words culturology, contemporary language, specialists, unreliability of cultural, proverbs, phraseological units, folklore genres, communication, cultural ideas

It is precisely these features that make culturology a re-enriching sphere in which specialists of the most diverse, often dissimilar areas can find lexical units enriched by its main feature - a semantic synthesis reflecting the integrative nature of this science.

The reduction of different forms for the designation of similar or approximate concepts helps to isolate concepts, the appearance of which sometimes erroneously define only "a tribute to fashion." Cult urology reflected in the language and enriching the language, is a dynamic space 
imbued with a dialectical interaction of the objectively existing qualities of both the external and internal world.

The first impression of chaos, cacophony, mixing of different ingredients on the basis of cognitive rapprochement of antithetic representations give rise to the erroneous idea of "non-seriousness", unreliability of cultural science as a science breaking all stable semantic relations.

The conceptual design of this material allows us to isolate from this material the main clusters of concepts that reflect the evolution of cultural meanings, on the one hand, and the actual, current, acute-modern meaning - on the other. Here it is possible to combine tradition and innovation in concept grams with varying degrees of assumptions, but carrying many facts of the history of culture and artifacts of the surrounding world, which can be generalized only when they are brought together.

Take, for example, the profession of mass-entertainer, an integral figure of holidays, resorts, tourist centers and other places of recreation, which formed the basis and color of the recreational culture of the Soviet period of our history. Then, to the ears of an unsophisticated citizen of the society of "developed socialism", information on DJs on the western dance floors, capable of skilfully managing the mood of the dancers, with their gestures, cries, cries, additional socio-cultural functions, then combined into DJing as an art form. Outwardly, they seemed diametrically dissimilar Social Science and Humanities 
to their Soviet counterparts, but in essence, they coincided in functions and in many other aspects.

Nowadays, a person who does not allow, "Pauses". Emotional "emptiness", stops during a particular solemn and festive evening, a feast, a "corporate", etc. Called "animator". Its main functions are to accompany and entertain guests, warming up their interest in the action. The organizer of cultural leisure often acts under the guise of any characters of animated and feature films. In addition, this is not accidental.

It is known that animation is called drawing, animated films, which need to be "animated" - to make it sound, move, react - in a word to behave like living characters. The animator performing at the party is like a lively start among the "cartoonish" ones, i.e. unreal, heroes of the evening. Therefore, in the name of this profession reflected non-communication, stiffness, complexion, the lack of spontaneous artistic reaction to what is happening participants such a "celebration." A complex of similar qualities is inherent in the psychology of a mass contemporary, endowed with a sense of perfectionism, professionalism, loaded with different technologies, not trusting his reactive personal capabilities, which have lost their immediacy. This "inside" of the internal state of a person is indicated only by the movement of a word from one sphere to another, behind which the process of complex cultural changes is hidden. 
Another example, caused by the proliferation of non-normative vocabulary to all levels of public life, reflects the aberration of individual and collectivist consciousness. Conflict of the normative paradigm of cultural values with a new social environment is resolved by expanding the range of negative evaluation tools. Non-normative vocabulary, as in the previous case, loses its connection with the original source of its origin, falls into another context and generates a special communicative aspect.

Thus, cultural linguistics reflects the processes of social psychology in the modern world and translates them into conceptual series. The interpretation of culturology as a new philosophy that is above the traditional philosophical divisions - axiology, anthropology, etc. - is in many respects still an unsolved problem, although its practical solution is diverse

Culturological ontology, in particular, is closely connected with linguoculturology and linguistic culture, which makes it possible to use its methodology effectively in comprehending the so-called "alien experience", in the development of modern comparativistics, and the renewal of humanitarian technologies.

The general significance of these conclusions is the translation of the direct cultural Experience in the consciousness of man, and today this is a necessary task in the formation of a new level of existence of culture.

Linguistic-cultural studies as a discipline 
Beginning at the end of the 20th century, linguoculturology gradually replaces regional studies in a didactic way. Since the last two decades of the XX century, the term linguoculturology has been increasingly used in conjunction with the term lingvostranovedenie. This requires a modification of the didactic coordinate system: instead of the system of "teaching the language - acquaintance with culture", the focus is on the relationship between communicative competence, linguoculturology and linguistic culture in the system "language teaching - familiarization with culture - language training". Recently, the field of view of scientists has been the problem of linguistic and intercultural competence of the individual. Such competence is manifested in the forms of written and oral communication: (a) in the possession of several genres of discourse possessing a high degree of linguistic cultural marking, (b) in the possession of ritualized forms of discourse whose violations are perceived by representatives of this linguoculture as inadequate communicative behavior.

Like linguistic culture, linguoculturology studies the relationship between language and culture, however, unlike linguistic studies; the emphasis is on the linguistic aspect. Linguistic culture is associated with lingvostranovedenie as a system of guidelines for solving general educational and humanistic problems, but at the same time. Linguoculturology has a number of specific features: 
- It is a synthesizing discipline occupying a boundary position between the sciences studying culture and philology;

- The subject of research lingvokulturologii serves spiritual and material culture, verbalized artifacts, forming a "linguistic picture of the world";

- linguoculturology is guided by a new system of cultural values, advanced by modern society, to objective information about the cultural life of the country.

In linguoculturology, a higher and abstract level of description of the problem of the relationship between language and culture is given. There is a need for a comprehensive account of three criteria: 1) language, which includes the frequency of the use of language units, taking into account the given boundaries; 2) familiarization, which is realized in the concept of educational and methodological expediency; 3) culturological, which takes into account the degree of importance and priority of information from the position of this branch of knowledge.

The analysis of methodological literature has made it possible to define the linguistic and cultural approach as one of the most effective ones aimed at developing and improving the skills and abilities of intercultural communication by studying the language as a cultural phenomenon. The result of the formation of secondary cognitive consciousness among students by mastering a foreign language is the acquisition of their ability Social Science and Humanities 
for intercultural communication. Along with the language with this approach, culture is the main content of training, which meets the psychological characteristics of learning a foreign language. The linguistic and cultural approach makes it possible to avoid the simplified factualfragmentary familiarization of trainees with certain aspects of culture and allows students to form a fairly complete picture of "foreign language reality" by studying both the linguistic and extralinguistic content of those selected for study.

Consequently, when culture is seen as an object of learning, the presentation of the material is built on the principle of "from the cultural unit", and not from the language one. Linguistic and cultural competence takes the form of linguistic, but it turns out to be meaningfully more profound. We believe that the formation of linguocultural competence can be defined as the goal of teaching a foreign language at an early stage, since it is precisely it that implies the penetration of the cultural meaning attached to a certain linguistic sign in nature.

Thus, the linguistic picture of the world deepens to the linguocultural picture of the world as a system of knowledge about culture embodied in a certain national language, and individual use of linguocultures is replaced by linguocultural competence as a socially significant system. The ability to intercultural communication is the result of the formation of secondary cognitive consciousness in students by mastering a foreign language as a Social Science and Humanities 
foreign language, which can be achieved through a linguocultural study of representative fragments of culture. Thus, under the linguistic and cultural approach, culture becomes the object of cognition and learning.

\section{References:}

1. Lemov AV System, structure and functioning of the scientific term (on the basis of Russian linguistic terminology). - Saransk: Publishing house of the Mordovian University, 2000.

2. Maslova VA Lingvokulturologiya: Proc. Allowance for stud. Supreme. Tutorials, institutions. - Moscow: Publishing Center "Academy", 2001.

3. Ter-Minasova SG Language and intercultural communication. - 2 nd ed., Dorab. - Moscow: Publishing House of Moscow State University, 2004. 
American Journal of Research

№ 2 (2), February 2017

The author information

Full name of participant

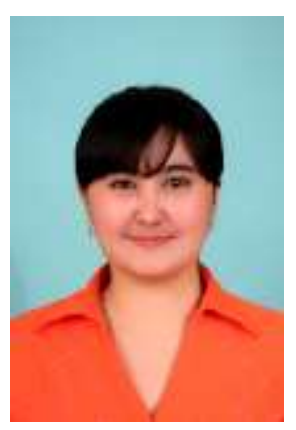

www.journalofresearch.us

info@journalofresearch.us

\section{Nargiza \\ Khodjaqulova \\ Khosiyatqulovna}

Academic title PhD, MA

etc.

A senior teacher of English language

Name of University,

Institution Company name,

Country

E-mail

Phone number
Tashkent University of Information

Technologies

nargiza.khodjaqulova@mail.ru

+998935845110, +998977375110

Address: Tashkent, Uchtepa borough, 30 - 9-14. Tel: +99890 1741488

Social Science and Humanities

51

Generalization of Scientific Results

USA, Michigan 
American Journal of Research

№ 2 (2), February 2017 www.journalofresearch.us

info@journalofresearch.us

\title{
MUBORAK NORKHODJAEVA
}

\author{
Uzbek State World Languages University 2-English faculty
}

\section{MODERN PEDAGOGICAL TECHNOLOGIES IN}

\section{TEACHING FOREIGN LANGUAGES}

The article is about the use of modern pedagogical technologies in teaching foreign languages, their advantages and positive effect in developing students' communicative competence. It shares with some nontraditional forms of conducting lessons which provide an opportunity to develop the creative independence of students, to teach them to work with various sources of knowledge.

Key words: communicative competence, pedagogical technologies, nontraditional methods, teaching process, intercultural communication

Under the Law of the Republic of Uzbekistan "On Education" and the National Program of Personnel Training a comprehensive system of teaching foreign languages, and the further integration of the republic into the world community was established in the country. To accomplish the mentioned aims on December 2012 the presidential decree "On Measures for Further Improvement of Foreign Languages Learning System" was adopted in Uzbekistan.

Social Science and Humanities 
According to it, the new level system determining a student's command as a foreign language CEFR (A1 - C2) which is commonly accepted in Europe was established in Uzbekistan. Each level is characterized by a set of certain communicative skills. And in order to develop these communicative skills in students, teachers should apply new modern information and pedagogical technologies in teaching foreign languages $[2,56]$.

With this reason nowadays the problem of teaching English is very urgent. The teacher is faced with the task of forming a personality that will be able to participate in intercultural communication. Increasingly, the question of the use of new information technologies in teaching process is being raised. And these are new forms and methods of teaching, a new approach to the learning process as a whole. The main purpose of teaching English is to form and develop a communicative culture of students and to learn how to master the foreign language on the basis of the target language.

The lesson is the basic organizational form of education. A good lesson is difficult. The art of the lesson depends on the understanding and fulfillment of the teacher's requirements, which are determined by the tasks and principles of instruction $[1,92]$. Creating the conditions for practical mastery of the foreign language and choosing the training methods are the Social Science and Humanities 
main task of the teacher. The global goal of the foreign language lesson is to become involved in a different culture and participate in the dialogue of cultures $[3,191]$.

Currently, a large number of modern pedagogical technologies are being used in teaching process: training in cooperation, project methodology, and Internet resource. Here huge possibilities of the Internet resource should be taken into account. It creates the conditions for obtaining any information: regional geographic material, information about the life of young people in the countries of the studied language, newspaper or magazine articles, and much more.

Using information resources of the Internet, you can more effectively solve didactic problems in the lesson: improving the ability to audit based on authentic texts, replenishing the vocabulary with the vocabulary of modern language, the formation of a steady motivation for learning English.

Interactivity does not just create real life situations, but it also forces students to respond adequately to them through the English language. And when it starts to work out, we can talk about language competence, even if there are errors. The main thing is the ability to react spontaneously to the statements of others. 
When working with a computer, the role of the teacher changes, the main task of which is to support and guide students. Relations with students are built on the principles of cooperation and joint creativity by increasing independent and group work, the volume of practical works of search character increases.

Another form of non-traditional lesson is the method of projects. The project methodology differs in the cooperative nature of the tasks at work on the project. This work assumes a high level of individual and collective responsibility for the performance of each task. When selecting the topic of the project, the teacher focuses on the interests of the students, on the already acquired knowledge and skills. The completed project can be in different forms: an article, a recommendation, an album, etc. The forms of the presentation of the project are also diverse: a report, a conference, a contest, a holiday, etc. The role of the teacher is to prepare the students for the project, to select the topic, to help the students at work, to monitor and advise students on the project as an accomplice.

Another unconventional form of conducting a lesson is a lessonexcursion. The student should be able to conduct a tour of the city, tell the guests about the identity of the culture of the peoples living here. The principle of dialogue of cultures assumes the use of cultural material about the native country, republic, city, etc. Other kinds of lessons are also can be Social Science and Humanities 
applied such as lesson-performance, lesson-holiday, lesson-interview, etc. Preparation and conducting of lessons of these types stimulates students to further study of English, and broadens their horizons.

The effectiveness of the learning process depends on the teacher's ability to correctly organize a lesson and choose the right form of the lesson. Non-traditional forms of conducting lessons provide an opportunity to develop the creative independence of students, to teach them to work with various sources of knowledge. But it should be noted that it is not advisable to apply too often to similar forms of conducting lessons. This will lead to a drop in students' interest in the subject.

To conclude we may say that the key to successful speech activity of students is the skilful use of modern and non-traditional forms of lessons by teachers, when students join the culture of the countries of the studied language, expand knowledge about the cultural heritage of their native country, which allows them to actively participate in the dialogue of cultures 


\section{REFERENCES:}

1. Гальского Н.Д. Современная методика обучения иностранным языкам, М.: АРКТИ, 2003

2. Danny Gagnon, Developing Effective Communication Skills, Montreal University, 2011

3. Lustig Myron W., Koester Jolene. Intercultural Competence: Interpersonal Communication Across Cultures, Pearson, Boston, 6th Edition, 2010 
American Journal of Research

№ 2 (2), February 2017 www.journalofresearch.us

info@journalofresearch.us

\title{
Mukhitdinova Firyuza Abdurashidovna
}

Doctor of Law, Professor of Tashkent State Law University (Republic of Uzbekistan)

\section{NEW STAGE OF REFORMING PREPARATION OF LEGAL STAFF IN THE REPUBLIC OF UZBEKISTAN}

In this article, it is planned to consider a number of issues relating to the system of training legal personnel and scientific workers in jurisprudence.

Of course, the training of legal cadres has its own specific features.

Keywords: jurisprudence, legality, practice, skills, personnel

\author{
Мухитдинова Фирюза Абдурашидовна \\ доктор юридических наук, профессор Ташкентского \\ государственного юридического университета (Республика \\ Узбекистан)
}

НОВЫЙ ЭТАП РЕФОРМИРОВАНИЯ ПОДГОТОВКИ ЮРИДИЧЕСКИХ КАДРОВ В РЕСПУБЛИКИ УЗБЕКИСТАН

В данной статье планируется рассмотреть ряд вопросов, касающихся системы подготовки юридических кадров и научных Social Science and Humanities 
American Journal of Research

№ 2 (2), February 2017

работников по юриспруденции. Конечно же, подготовка юридических кадров имеет свои специфические особенности.

Ключевые слова: юриспруденция, законность, практика, навыки, кадры

В новейшее время остается актуальным высказывание известного философа А. Эйнштейна "Наука - это неустанная многовековая работа мысли свести вместе посредством системы все познаваемые явления нашего мира". В настоящее время, когда право в нашем государстве нашло свое место, только немногие люди интересуются тем, какое место занимает и какое влияние оказывает теория государства и права на состояние современного правосознания. Появляется множество вопросов о роли теории в образовании, о том, как она влияет на профессиональную деятельность юристов. Чтобы ответить на эти вопросы, требуется разобраться во внутренней структуре теории государства и права, понять ее функции, найти ее связь с другими юридическими науками. Многие ученые-правоведы, в своих работах раскрыли понятие теории государства и права, указали ее особенности и функции. Юридические науки - это система очень разнообразных знаний, объединенных одним объектом. Этим объектом выступает государство и право. Вся система юридических наук, по мнению многих авторов, делится на определённые группы. Social Science and Humanities 
American Journal of Research

№ 2 (2), February 2017 www.journalofresearch.us info@journalofresearch.us

Это - исторические, отраслевые, прикладные, теоретические. К историческим наукам мы можем отнести историю государства и права Узбекистана, историю государства и права зарубежных стран и др. К отраслевым относятся те науки, которые изучают отрасли права. А к теоретическим - теория государства и права и другие науки, которые сложились из частных теорий различного рода происхождения. Изучая государство и право в целом, государственно-правовая теория не ограничивается опытом только данной страны или региона, а на основе изучения государства и права различных исторических эпох всех областей и направлений государственно-правовой действительности, определяет общие и специфические закономерности их развития, основные признаки и существенные характерные черты. Теория государства и права выделяется в системе юридических наук как самостоятельная научная отрасль знаний, так как в реальной науке действуют объективные государственноправовые закономерности. Наиболее важно из познание, без которого невозможно глубокое усвоение всего, что изучают юридические науки. И без фундаментальных понятий о сущности права и формах государства, их структурах, социальной роли и назначении невозможно выяснить особенности различных государств. Общая теория государства и права по отношению к отраслевым и специальным юридическим наукам выступает обобщённой наукой, Social Science and Humanities 
American Journal of Research

№ 2 (2), February 2017 www.journalofresearch.us info@journalofresearch.us

которая имеет руководствующее направление и методологические значения. Необходимость разработки достаточно узких проблем, стоящих перед юридическими науками ставит теорию государства и права в руководящее положение. То есть она освобождает другие науки от исследования этих проблем. В рамках общей теории государства и права формируются основные правовые категории, которые служат базой для других юридических наук. Эта наука интегративна, т.к. связанна со многими науками об обществе. И это логично, ведь теория государства и права связана с экономикой, политическим движением классов, моралью, культурой, языком и т.Д. поэтому мы можем наблюдать связи теории государства и права с другими юридическими науками: политологией, социологией, философией, этикой, логикой, социальной психологией. Теория государства и права, как и любая другая юридическая наука, имеет свои функции, которые дают полное представление о ней и о направлении научной деятельности. Функции теории государства и права взаимосвязаны, дополняют друг друга. Только все вместе дают полное представление о назначении теории государства и права.

Ведь высшее юридическое образование направлено на подготовку высококвалифицированных, широко образованных специалистов, которые будут способны к участию в государственноправовой жизни, и будут обладать надлежащей политической и Social Science and Humanities 
American Journal of Research

№ 2 (2), February 2017 www.journalofresearch.us info@journalofresearch.us

правовой культурой. Узко профессиональная подготовка здесь не подходит, поскольку она не только уменьшает интеллектуальный потенциал юриста, но и не соответствует его профессиональной деятельности как социально политической. Ясно, что юристам специалистам надо хорошо знать то, что имеет значение для решения юридических дел, т.е. содержание конкретных законов, порядок осуществления юридических процедур и т.п. Но, что бы понять всё это, надо использовать глубокие научные знания о государстве и праве, необходимости верховенства закона во всех сферах жизни общества. Поэтому значение теории государства и права очень важно, т.к. она раскрывает мировоззренческий спектр государственноправовой жизни и юридической деятельности.

Будущее любой страны во многом зависит от государственной политики в сфере образования, особенно это, важно для юриспруденции. Конечно, нельзя сказать, что для других отраслей образования это маловажно, но в настоящее время современному обществу просто необходимы образованные юристы, которые бы понимали структуру и значение государства и права.

Наука и образование расширяют кругозор современного человека и позволяют формировать его личность. Роль науки и образования в модернизации общества и государства велика, и данный вопрос не нуждается в лишних комментариях. Однако, как Social Science and Humanities 
American Journal of Research

№ 2 (2), February 2017 www.journalofresearch.us info@journalofresearch.us

мы знаем, система образования и науки Узбекистана переживает период модернизации и, в свою очередь, со стороны государства делается многое для успешного и системного перехода этой сферы на мировые стандарты. В этой связи среди ученых-юристов и юристовпрактиков часто поднимается вопрос о совершенствовании системы подготовки юридических кадров.

Чтобы решить этих проблем, Президент Узбекистана Шавкат Мирзиёев 28 апреля подписал постановление «О мерах по коренному совершенствованию с системы и повышению эффективности подготовки кадров в Ташкентском государственном юридическом университете».

В соответствии с документом в структуру Министерства юстиции введена должность заместителя министра юстиции ректора ТГЮУ.Ожидается, что это повысит эффективность подготовки высококвалифицированных юридических кадров и позволит более активно вовлекать ТГЮУ в процессы государственного строительства и демократизации общества, реализации приоритетных задач социально-экономического развития и реформирования судебно-правовой сферы.

Это даёт возможность реализовать на практику значения и роли право в обществе и формированию правового государства. Ведь, как нам известно, право как регулятор общественных отношений выстуSocial Science and Humanities 
American Journal of Research

№ 2 (2), February 2017 www.journalofresearch.us info@journalofresearch.us

пает важнейшим фактором социально-экономического развития общества. Поэтому право имеет определенную социальную ценность. Понятие ценности права призвано раскрыть его положительную роль для общества, отдельной личности.

В общесоциологическом смысле понятие социальной ценности характеризует те явления объективной действительности, которые способны удовлетворять определенные потребности социального субъекта, необходимые, полезные для его существования и развития. Понятие ценности права, следовательно, призвано раскрыть его положительную роль для общества, отдельной личности.

Отсюда ценность права - это способность права служить целью и средством для удовлетворения социально справедливых, прогрессивных потребностей и интересов граждан, общества в целом.

Ценность права заключается в том, что оно: способствует развитию тех отношений, в которых заинтересованы как отдельные индивиды, так и общество в целом, согласует их интересы; во-вторых, обладает организующим началом, придает действиям людей организованность, устойчивость, согласованность, обеспечивать их подконтрольность, делает отношения цивилизованными; м в третьих, является выразителем и определителем (масштабом) свободы личности в обществе, определяет границы и меру этой свободы; · воплощает идеи справедливости; выступает фактором прогресса, источником Social Science and Humanities 
American Journal of Research

№ 2 (2), February 2017 www.journalofresearch.us info@journalofresearch.us

обновления общества в соответствии с историческим ходом общественного развития; является средством решения международных $\quad$ и межнациональных проблем $\quad$ и достижения социального мира и согласия, средством снятия напряженности в обществе; способствует решению экологических проблем как внутри отдельно взятого государства, так и в рамках мирового сообщества.

Поэтому предусмотрена оптимизация учебной нагрузки в университете, а именно - сокращение продолжительности теоретического обучения путем введения отдельного периода самостоятельной подготовки и увеличения продолжительности аттестации.

А также очень важно отметить что в дальнейшем ТГЮУ предоставлено право самостоятельно разрабатывать и утверждать учебно-нормативные документы, такие как квалификационные требования к выпускникам, учебные планы и учебные программы с учетом потребностей практики. Это позволит своевременно адаптировать учебный процесс кпотребностям работодателей, а также динамично развивающейся юридической науке и правоприменительной практике на глобальном уровне. Вовторых, предлагается усовершенствовать механизм прохождению практики студентов в правоохранительных органах. Если посмотреть на зарубежный опыт, например, в германской образовательной Social Science and Humanities 
American Journal of Research

№ 2 (2), February 2017 www.journalofresearch.us info@journalofresearch.us

системе практическое образование длится два года, во время которого обучающийся проходит стажировку. В течение этого времени выпускник бакалавриата после учебы должен пройти обязательную стажировку в ряде учреждений (5 месяцев - в суде по гражданским делам, 3 месяца - в прокуратуре или суде по уголовным делам, 3 месяца - в административных органах, 10 месяцев у адвоката, 3 месяца - в избирательных органах). За время стажировки выпускники получают разнообразные практические навыки. Для этого им предоставлены достаточно широкие права - например, обучающиеся могут присутствовать в совещательной комнате при вынесении судебного решения. Это специально регламентировано в законе о судоустройстве. По окончании стажировки выпускники получают удостоверение о прохождении стажировки в каждом из перечисленных выше учреждений. В удостоверениях отмечаются содержание стажировки и достижения стажера. И главное, государственные экзамены у выпускников принимаются органами юстиции соответствующих земель.

Особенностью данного указа является в том, что, предусмотрено создание попечительского совета ТГЮУ. Он будет участвовать в вопросах эффективного сотрудничества с государственными, общественными и бизнес-структурами по трудоустройству выпускников, поддержки новых форм, программ и Social Science and Humanities 
American Journal of Research

№ 2 (2), February 2017 www.journalofresearch.us info@journalofresearch.us

перспективных инициатив, способствующих развитию высшего юридического образования, эффективного внедрения результатов научных разработок в законотворческую деятельность и правоприменительную практику, развития практики заключения партнерских соглашений о сотрудничестве и их практической реализации, установления и развития международного сотрудничества в сфере образования и науки, улучшения условий труда и социального обеспечения педагогических и иных работников ТГЮУ, организации финансовой помощи вузу, содействия привлечению внебюджетных средств пожертвований для обеспечения его деятельности и развития.

Постановлением утверждена обновленная организационная структура ТГЮУ, направленная на повышение качества и эффективности управления университетом. Среди изменений создание Отраслевого центра переподготовки и повышения квалификации педагогических кадров при ТГЮУ со статусом юридического лица на базе Факультета переподготовки и повышения квалификации педагогических кадров. Это соответствует установленной в системе высшего юридического образования структуре переподготовки и повышения квалификации педагогических кадров.

Social Science and Humanities 
American Journal of Research

№ 2 (2), February 2017 www.journalofresearch.us info@journalofresearch.us

Новые требования к подготовке юридических кадров ставят Стратегия действий по пяти приоритетным направлениям развития Узбекистана в 2017-2012 годах, а также ряд последних документов, подписанных главой государства. Например, указом Президента от 21 февраля «О мерах по коренному совершенствованию структуры и повышению эффективности деятельности судебной системы Республики Узбекистан» предусмотрено образование районных (городских) административных судов, создание 71 межрайонного, районного (городского) экономического суда, введение в структуры судов должностей старшего помощника, помощника судьи с упразднением должности секретаря судебного заседания. Для укомплектования вновь создаваемых судов дополнительно выделяются 560 штатных единиц управленческого персонала, в том числе 318 судей.

Постановление Президента от 1 февраля «О дополнительных мерах по совершенствованию механизмов оказания государственных услуг субъектам предпринимательства» центры «одно окно» переданы из структуры хокимиятов районов и городов в ведение Министерства юстиции. Это обстоятельство, а также требование о наличии юридического образования у сотрудников центров «одно окно» показывают необходимость дополнительно 310 юридических кадров. Вместе с тем, на данный момент 720 единиц на должность Social Science and Humanities 
American Journal of Research

№ 2 (2), February 2017

юрисконсульта

хозяйствующих

субъектах

info@journalofresearch.us вакантными.

В целях формирования реального сотрудничества между работодателями и юридическим университетом предлагается часть некоторых кафедр факультета, например уголовного права, уголовнопроцессуального права, гражданского, гражданско-процессуального права и т.п., открыть в самих правоохранительных и судебных органах, с тем чтобы студенты могли иметь возможность доступа на место практики в любое время учебного года. Это поможет студентам приобретать практические навыки, иметь непосредственный доступ к практическим материалам при решении казусов и написании итоговых а также дипломных работ. Данная новая модульная система послужит основой при подготовки юридических кадров Республики Узбекистан и эффективно и результативно применяется в формирование правового государства и в обеспечении верховенстве закона.

Social Science and Humanities 
American Journal of Research

№ 2 (2), February 2017 www.journalofresearch.us

info@journalofresearch.us

Мухитдинова Фируза Абдурашидовна -доктор юридических наук, профессор Ташкентского государственного юридического университета

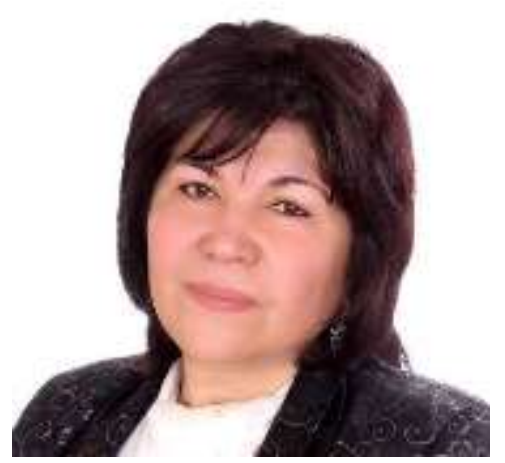


American Journal of Research

№ 2 (2), February 2017 www.journalofresearch.us

info@journalofresearch.us

\section{Muhayyo Rakhimova}

Senior Teacher National University of Uzbekistan

TO THE QUESTIONS OF SUPERVISION OF THE

INDEPENDENTS WORKS OF STUDENTS WHILE LEARNING

FOREIGN LANGUAGES

This article is about the notion of the independents works of students. In addition, his role and thinking in the process of foreign languages.

Key words: independent work, supervision, students, learning foreign languages, educational material.

К ВОПРОСУ О РУКОВОДСТВЕ САМОСТОЯТЕЛЬНОЙ РАБОТОЙ СТУДЕНТОВ ПРИ ИЗУЧЕНИИ ИНОСТРАННЫХ ЯЗЫКОВ

Мухайё Рахимова

Национальный университет Республики Узбекистан старший преподаватель

В данной статье речь идет о понятие самостоятельной работе студентов. Её роль и значение в процессе обучения иностранных языках.

Social Science and Humanities 
American Journal of Research

№ 2 (2), February 2017 www.journalofresearch.us info@journalofresearch.us

Ключевые слова: самостоятельная работа, руководство, студенты, изучение иностранных языков, учебный материал.

Самостоятельная работа студента занимает важное место в процессе обучения вообще и иностранному языку в частности.

Понятие самостоятельная работа сейчас несколько расширилось. Если раньше под этим термином понимали ту учебную работу, которая протекает без непосредственного руководства преподавателя и носит индивидуальный характер, то сейчас самостоятельная работа студента еще предусматривает и другую сторону освоения знаний, а именно творческую переработку знаний. Современный этап педагогической практики предполагает переход от традиционной технологии объяснения учебного материала к деятельноразвивающей технологии.

Для успешной самостоятельной работы студент должен обладать твердыми навыками и умениями.

Студентов необходимо учить самостоятельному приобретению новых знаний, как из книги, так и путем наблюдений и извлечения их из практики.

В тренировочных заданиях, имеющих целью выработку и совершенствование умений и навыков самостоятельной работы должны предусматриваться задания не столько на простое воспроизведение изученного, сколько на применение усваиваемых Social Science and Humanities 
American Journal of Research

№ 2 (2), February 2017 www.journalofresearch.us info@journalofresearch.us

правил, приемов, понятий в новых ситуациях, когда требуется новое комбинирование материала, его видоизменение и т.д.

В условиях, когда к самостоятельной работе предъявляются особые требования, видимо, должна произойти, и перестройка в работе преподавателей иностранных языков.

Не всегда и не везде преподаватели иностранных языков уделяют достаточное внимание тому, как работает студент самостоятельно, сколько времени тратит на выполнение того или иного задания, рациональными ли методами было выполнено им задание, умеет ли студент правильно пользоваться словарем, справочником, как запоминает слова и выражения, как использует технические средства обучения, выполнял ли студент задание формально или с интересом, узнал ли он что-либо в процессе его выполнения, какие возникли у него трудности, какой ценой ему удалось выполнить задание. Эти и многие другие важные вопросы часто бывают неизвестны преподавателю, т.к. его, как правило, интересует лишь окончательный результат выполнения задания.

Самостоятельная работа всегда вызывала и вызывает у студентов, особенно первых и вторых курсов, ряд трудностей, обусловленных необходимостью адаптации бывших школьников к новым формам обучения. Главная трудность связана с необходимостью самостоятельной организации своей работы. Многие студенты Social Science and Humanities 
American Journal of Research

№ 2 (2), February 2017 www.journalofresearch.us info@journalofresearch.us

испытывают болышие затруднения, связанные с отсутствием навыков анализа, конспектирования, умением четко и ясно излагать свои мысли, учитывать индивидуальные особенности своей умственной деятельности, практически полным отсутствием психологической готовности к самостоятельной работе, незнанием общих правил ее организации.

Самостоятельной работой студента необходимо руководить. Для этого требуется кропотливая индивидуальная работа. Необходимо знать, как работает студент по каждому аспекту языка самостоятельно, какие у него встречаются при этом затруднения.

Так как обучение-процесс двухсторонний, то от преподавателя требуется большая воспитательная работа. Самостоятельная работа в большой степени зависит от желания и стремления студента осилить тот или иной аспект языка или язык в целом.

Без желания выполнить задание, приобрести новые знания, без упорства в преодолении трудностей успеха быть не может. Поэтому от преподавателя требуется использование всех известных ему методов и средств, чтобы вызвать у студента интерес. Для этого преподавателю необходимо, прежде всего, показать практическую ценность и необходимость изучения иностранного языка.

Например, привлекая студента к чтению специальной литературы, подбирая материал для чтения, необходимо знать и Social Science and Humanities 
American Journal of Research

№ 2 (2), February 2017 www.journalofresearch.us info@journalofresearch.us

учитывать, над чем работает студент, какие готовит доклады, какую тему разрабатывает в научном кружке, какой предмет его больше всего интересует. Лучшие переводы должны обязательно быть использованы или на спец кафедрах, или в научной работе студента. Студента следует учить обдумывать, где и как можно использовать то, что он учит. Он должен четко знать, что ему учить и какова в этом необходимость.

Для выполнения СРС кафедра разработала домашние индивидуальные задания для студентов по основным разделам психолого-педагогических дисциплин. Индивидуальное домашнее задание выполняется студентом в течение семестра. Для успешной самостоятельной работы студента большое значение имеет подбор и выдача заданий для самостоятельной работы.

Мы часто не обнаруживаем потенциально хороших студентов только по тому, что они обучались на таких заданиях, которые не вызывали у них интереса. От преподавателя требуется глубокое проникновение в процессы познавательной работы студента, умение избегать подмены самостоятельной работы студента своими собственными объяснениями, обладание тонким искусством вести студента вперед в развитии его самостоятельности.

Индивидуальное семестровое задание оформляется в виде письменной работы, выполненной в соответствии с определенными Social Science and Humanities 
American Journal of Research

№ 2 (2), February 2017 www.journalofresearch.us info@journalofresearch.us

требованиями. В такой работе есть обучающий момент, так как студент осваивает принятый стандарт, выключающий нормы и правила изложения научного материала. В намеченный срок семестровое задание сдается преподавателю как отчет. Студент по своему желанию может выбрать любую из форм СРС, предлагаемых кафедрой в качестве индивидуального задания.

1. Написание реферативных работ на темы, связанные с различными разделами изучаемых дисциплин.

2. Изготовление иллюстративного материала по выбранной дисциплине, где тема определяется преподавателем, а содержание и форма, исполнения самим студентом.

3. Дискуссионное письмо (адресат, стиль и круг проблем для дискуссии определяются в соответствии с интересами студента).

4. Анализ сравнение двух или более научных концепций по конкретным параметрам, по способам решения одних и тех же проблем.

5. Опыт самостоятельного рассуждения, т.е. понятийной рефлексии по поводу научного вопроса, поставленного преподавателем с логически обоснованными выводами.

6. Конспектирование разделов учебника по определенной теме с приведением собственных примеров.

Social Science and Humanities 
American Journal of Research

№ 2 (2), February 2017 www.journalofresearch.us info@journalofresearch.us

Отдельными студентами выполняются реферативные работы. Цель такой работы-выявить творческие личности и приобщить их к индивидуальной исследовательской работе. На их основе позже формируются группы по научным интересам преподавателей.

Самостоятельную работу студентов можно организовать и на лекциях. Преподаватель разрабатывает конспект лекций, включающий основные блоки изучаемого материала, проблемные вопросы к ним, рисунки, таблицы (если они необходимы), специальные задания для дискуссии, вопросы и комментарии по каждой теме рекомендованного базового учебника ${ }^{15}$. К каждой лекции можно подготовить набор слайдов для кодоскопа, использование которого на лекции интенсифицирует работу преподавателя, способствует более доступному и наглядному изложению материала. В комплекте лекций необходимо предусмотреть на каждой странице поля для записи комментариев студентов. Конспект лекций каждый студент получает заранее. Работа на лекции организуется следующем образом: студенты дома прорабатывают материал каждой последующей лекции и готовят свои вопросы. Преподаватель ведет лекцию в активной диалоговой форме, обсуждая вопросы, сформулированные в конспекте, а также организуя дискуссию с

\footnotetext{
15 Краля Н.А. Метод учебных проектов как средство, активизации учебной деятельности
} учащихся.- Омск: Изд-во ОмГУ, 2005. С.4.

Social Science and Humanities 
American Journal of Research

№ 2 (2), February 2017

учетом вопросов, подготовленных студентами. При такой организации лекционный процесс перестает быть пассивным, а студенты большую часть материала усваивает в аудитории. При этом интенсифицируется не только деятельность преподавателя, но и студента. Всё это не только обогащает содержимое самостоятельной работы, но и позволяет решать ряд вопросов дифференцированного или индивидуального обучения.

Любой вид самостоятельной работы принесёт результат только тогда, когда он будет замечен и объективно оценён. В организации самостоятельной работы студентов решающую роль играет преподаватель. Его методическая подготовка, мастерство, инициатива обеспечивают успешное овладение студентами рациональными методами, самостоятельно приобретать знания и их использовать.

Social Science and Humanities 